\title{
Should the silviculture of Aleppo pine (Pinus halepensis Mill.) stands in northern Africa be oriented towards wood or seed and cone production? Diagnosis and current potentiality
}

\author{
Wahbi Jaouadi ${ }^{(1-2)}$, \\ Souheila Naghmouchi ${ }^{(3)}$, \\ Moodi Alsubeie ${ }^{(4)}$
}

\begin{abstract}
The aim of this work is to review studies on the silviculture of Aleppo pine ( $\mathrm{Pi}$ nus halepensis Mill.) in North Africa and the Mediterranean basin over a period of 50 years. The study presents a synthesis of: (i) silviculture; (ii) wood productivity and growth; (iii) cone and seed production; and (vi) the socio-economic role of Aleppo pine. The results show that the production of the Aleppo pine is enhanced by the potential of the site, which is closely related to the bioclimatic stage and soil fertility. For instance, production increased from $\mathbf{0 . 4}$ to $4 \mathrm{~m}^{3} \mathrm{ha}^{-1} \mathrm{yr}^{-1}$ in an Aleppo pine stand with a dominant height varying between 9.7 and $22.8 \mathrm{~m}$. Previous studies confirmed that the average maximum volume in annual growth of Aleppo pine is $3.3 \mathrm{~m}^{3} \mathrm{ha}^{-1} \mathrm{yr}^{-1}$ for 40 -year old stands at good-fertility sites. The lowest values $\left(<0.5 \mathrm{~m}^{3} \mathrm{ha}^{-1} \mathrm{yr}^{-1}\right)$ were recorded for the fourth and last class of productivity in $>100$-year old stands. There is high demand for Aleppo pine seeds in North Africa, making their production profitable, and this represents an important sector for the sustainable development and improvement of living-standards of the local populations. There has been a steady increase in the demand for seeds across years, with seed production becoming a very promising niche. Silviculture oriented towards the commercial production of seeds is expected to enhance this species, as well as facilitate its preservation.
\end{abstract}

Keywords: Aleppo Pine, Pinus halepensis Mill., Silviculture, Wood Production, Seed Production, Socio-economic Role

et al. 2000), Italy (Ciancio 1986), Algeria (Bentouati 2006), and Tunisia (Souleres 1975, Souleres 1969, Chakroun 1986, Ammari et al. 2001, Sghaier \& Garchi 2009, Sghaier \& Ammari 2012). Because of its low requirements and high plasticity, Aleppo pine has been extensively used as a reforestation species to restore degraded areas. Indeed, Aleppo pine is one of the few species that easily grows on poor and dry soils. In semi-desert regions, particularly in Libya, this species is distinguished by its tolerance to drought, growing in areas with $250 \mathrm{~mm}$
(1) Silvo-Pastoral Institute of Tabarka, University of Jendouba, BP 328, 8110 Tabarka (Tunisia); (2) National Institute of Research in Rural Engineering, Waters and Forests, University of Carthage, BP. 10, Hédi Karray Street, Menzeh IV, Ariana 2080 (Tunisia); (3) Princess Norah Bint Abdurrahman University, College of Sciences, Biology department, Riyadh (Saudi Arabia); (4) Imam Muhammed bin Saud Islamic University, College of Sciences, Biology department, Riyadh (Saudi Arabia)

@ Wahbi Jaouadi (jaouadiwahbi@gmail.com)

Received: Sep 28, 2018 - Accepted: Mar 16, 2019

Citation: Jaouadi W, Naghmouchi S, Alsubeie M (2019). Should the silviculture of Aleppo pine (Pinus halepensis Mill.) stands in northern Africa be oriented towards wood or seed and cone production? Diagnosis and current potentiality. iForest 12: 297-305. - doi: 10.3832/ifor2965012 [online 2019-05-27]

Communicated by: Tomás Vrska annual rainfall. However, the species cannot withstand prolonged periods of frost and is vulnerable to heavy snowfall, as its branches are fragile and easily broken ( $\mathrm{Ri}$ codeau 2013). In Tunisia, Aleppo pine forests (Pinus halepensis Mill.) have fundamental environmental, economic, and social roles. According to the last national forest inventory (DGF 2010), pure stands of Aleppo pine cover an area of 361,222 ha. The average increase in height and diameter of this species does not exceed $7 \mathrm{~cm}$ year ${ }^{-1}$ and $0.25 \mathrm{~cm}$ year ${ }^{-1}$, respectively (Belghazi 1998). Many stands of Aleppo pine originate through reforestation activity. Since 1988, planting densities in Tunisia were reduced from 2500 to 1600 trees ha- ${ }^{-1}$. Consequently, because of the mechanization of soil preparation, particularly in the richest sites, the production of Aleppo pine stands has increased from 6 to $8 \mathrm{~m}^{3} \mathrm{ha}^{-1} \mathrm{yr}^{-1}$ (Jalel 1996).

\section{Silviculture of Aleppo pine stands}

\section{Thinning}

Thinning is a treatment used to improve the structure of growing forest stands. Thinning gives rise to woody samples or intermediate products that can be marketed. For a forest stand, thinning enhances the availability of water to trees (Breda et al. 1995, Ducrey \& Huc 1999, Jiménez et al. 
2008) and decreases the magnitude and duration of water stress (Aussenac 1987). According to Donner \& Running (1986) and Misson et al. (2003), thinning improves the resistance of trees to drought, at least in short term (within about 5 years of thinning). In fact, there is no ideal thinning regime across all forest stands, because each stand occupies a site with unique characteristics. However, within the same forest compartment, several successive clearings are made before regeneration method (Alaoui et al. 2011). Belghazi (1998) concluded that the periodicity of thinning could be decided with a fixed rotation every 10 years. Boudy (1952) observed that thinning rotation ranges between 6 and 15 years, in general. Bentouati (2006) reported that, in Algeria, the Aleppo pine has a very high juvenile growth rate. This suggestion was confirmed by stem analyses, which showed a gain in height of $20 \mathrm{~cm}$ year ${ }^{-1}$ during the first 40 years, $15 \mathrm{~cm}$ year between 40 and 80 years, and a gradual decline to $5 \mathrm{~cm}$ year-1 after 100 years. Montero et al. (2001) used a rotation from 10 years when constructing Aleppo pine production tables in Spain. Frantz \& Forster (1979) adopted a rotation of five years in Beni-Imloul in Algeria. Couhert \& Duplat (1993) chose a variable rotation strategy based on the fertility classes adopted in France. In Morocco, Alaoui et al. (2011) distinguished two distinct periods of rotation for thinning Aleppo pine stands: every five years in reforested Aleppo pine stands and every 10 years in natural stands. In Tunisia, $70 \%$ of Aleppo pine stands are less than 60 years old, with thinning practices reflecting this status (Sghaier \& Ammari 2012). In Algeria, Bentouati (2006) suggested that thinning intervenes with the removal of dominant trees, benefitting future elite trees only. In France, Couhert \& Duplat (1993) recommended the use of high intensity thinning to eliminate almost $43 \%$ of trees from first class of fertility that are 43years old. In the Beni-Imloul massif in Algeria, Frantz \& Forster (1979) practiced intensive thinning, which was justified mainly because of the advanced age of most forest stands and because of the health status of trees that had been attacked and infected/infested by insects and diseases.

\section{Age of operability of Aleppo pine stands}

The current annual increment (CAI) and mean annual increment (MAI) curves converge with age. The highest point of the $M A I$ is the age used to determine the age of operability of Aleppo pine stands in management. It is possible to use this indicator (age of operability) to maximize wood production in forest stands (Clutter et al. 1983, Davis \& Johnson 1987, Davis et al. 2001). According to Chakroun (1986), the age of operability of Aleppo pines in Tunisia corresponds to an average diameter of $30 \mathrm{~cm}$. According to Bentouati (2006), this age is set between 70 and 90 years, depending on fertility classes. Sghaier \& Ammari (2012) showed that, for Aleppo pine in Tunisia, the age of operability for the first productivity class is about 50 years, while it is 80 years for the second class and exceeds 100 years for the third class.

\section{Silviculture of Aleppo pine stands after fire}

Aleppo pine is very sensitive to fire, which causes the cones to burst, thus facilitating regeneration. Seed dispersal is favored by wind and animals. Germination begins after the first rains, towards the end of summer, and continues over the rest of the year (Vennetier 2003). Following fire, natural regeneration leads to the formation of a very dense thicket stage during earliest years. This excessive density leads to slow growth, caused by competition between young plants and a decline in stand vigor. In this case, it is necessary to intervene as soon as possible by implementing cleaning operations aimed to reduce the number of seedlings and regulate density. Intervention in regeneration is obligatory in the young forest compartment, and improvement operations must be gradual and repeated at short intervals (Bentouati 2006).

\section{Management of Aleppo pine forests}

Aleppo pine forests are managed as evenaged forest. This type of treatment makes thinning interventions economically feasible (Vennetier et al. 2010). A study by Bentouati (2006) showed that the structure of natural Aleppo pine forests is clumped in Aurès-Algeria. Therefore, regeneration was achieved by clear-cutting small areas in mature stands. These cut surfaces in stands grew as the seedling developed from 10 to 20 years.

Chakroun (1986) proved that the evenaged forest regime in Tunisia is the most appropriate for managing Aleppo pines, because it is simple to apply. Nevertheless, the spatial typology of stands, which is generally clumped, implies the differentiation of interventions according to stand typology. While the basic unit of technical management in forest stands is the compartment, compartments are grouped into regeneration, improvement, and/or reconstitution areas, according to use and typology. The management planning period is usually 20 years in Tunisia.

\section{Natural regeneration of Aleppo pine forests}

To regenerate Aleppo pine forests, seeds must be regularly spaced and removed from the influences of man and animals (Nsibi 1997). In a study of the natural regeneration of Aleppo pine forests in Oum Jeddour (central Tunisia), Langley (1976) showed that the natural dispersal of seeds was weak in Aleppo pine stands. Consequently, spreading branches containing cones during thinning or clearcutting could increase the quantity of seeds dispersed.
Furthermore, tillage associated with high cover density facilitates the establishment of seeds.

Acherar et al. (1984) showed that the colonization of Aleppo pines is restricted to a limited distance from the parent tree, with just 3\% of seeds falling more than $24 \mathrm{~m}$ from the parent tree. Seeds germinate quickly, with the germination rate being high during the wet season. However, despite the high mortality of young seedlings, especially in the first two years, the loss of regenerated plants is compensated for by the production of large numbers of seeds and the high germination rate (Acherar et al. 1984). Quezel \& Médail (2003) reported that, even in dense Aleppo pine forests, regeneration is not a problem, as long as there is sufficient illumination. Bedel (1986) showed that Aleppo pines are easily regenerated, even on very degraded soils. Certain factors, like grazing and repeated fires, are likely to hinder the survival of young seedlings, weakening the success of natural regeneration. To obtain medium and sufficient regeneration in Aleppo pine forests, trees must be cut in the form of clumps, taking care to retain young trees that carry many vital seeds.

The selection of productive seed trees must be evenly distributed on the cutting area and preserved for 3 to 5 years until a total regeneration is achieved. A density of 50 pines per hectare is considered as the minimum threshold (D'hanens 1998). In rugged relief, cutting should be conducted in broad strips that are wide one to two times the height of trees. When there is invasive undergrowth of Aleppo pine, coppicing is necessary. Once regeneration is achieved, it is necessary to intervene starting from the $5^{\text {th }}$ year by cleaning and eliminating poorly trained trees. This operation aims to distribute seedlings optimally in the space, enhancing the living space of each individual and reducing the effect of competition. This approach allows future seedlings that establish to develop naturally, possibly facilitated by tillage (Neveux et al. 1986).

Regeneration is practiced by the localized clearcutting of mature stands in small areas, which increase in size as seedlings develop, followed by a set of protection over 10 years (Nsibi 1997). El Hamrouni \& Sarson (1975) showed that the density of seed trees does not limit the natural regeneration of Aleppo pines, rather the rate of undergrowth recovery. Thus, reducing cover causes the number of young pines to decrease, making regeneration difficult. Medium-density stands form canopies with a more or less continuous cover, which determines a microclimate favorable for seed germination and seedling development (Nsibi 1997). The authors also reported that seeding in dense stands produces a relatively high density of natural seedlings (i.e., from 2611 to 2739 seedlings ha-1, with a density of more than 500 trees ha ${ }^{-1}$ ). 
Stand density of Aleppo pines after regeneration

In the semi-arid conditions of Tunisia, Tschinkel (1976) demonstrated that the most suitable spacing for the reforestation of Aleppo pine was $1.5 \times 5 \mathrm{~m}$, corresponding to a planting density of 1300 plants ha ${ }^{-1}$. Sghaier \& Ammari (2012) reported that, by adopting average silviculture, stand density remained relatively high, exceeding 600 stems ha $^{-1}$ for stands up to $80-90$ years of age. This high density might reflect the fact that forests in Tunisia have always been protected, with silviculture being absent in most stands. Ciancio (1986) showed that a density of 2222 plants ha ${ }^{-1}$ with a rectangle layout (distance of $3 \times 1.5 \mathrm{~m}$ ) was the optimal density. Letreuch Belarouchi (1991) suggested that the optimal density would be 1100 plants per hectare, with a spacing of $3.5 \times 2.5 \mathrm{~m}$, reflecting that stated in the National Reforestation Plan. Bentouati (2006) suggested that the number of stems should be stabilized between 700 and 900 stems ha $^{-1}$ for pines of 20 and 30 years old, depending on the forest site. This suggestion is justified by the fact that the Aleppo pine is a light demanding species, with high density stands generally being characterized by slow growth. For reforestation, planting density is usually 1100 stems $\mathrm{ha}^{-1}$ in the plains and 830 stems ha in the mountains (Alaoui et al. 2011). An increase in density causes smaller spacing between trees, which leads to a decrease in growth (both diameters and height), due to inter-tree competition. Consequently, the volume and productivity of the entire stand decreases (Cherak 2010).

\section{Productivity and growth of Aleppo pine forests}

An important characteristic of forest stands for silviculturists to be precisely documented is wood production (Garbaye et al. 1970). Wood production corresponds to the volume of the tree, with and without branches, under bark. Wood volume is evaluated by scaling methods, using simple parameters, such as diameter (or circumference) and height measured on well-chosen trees distributed in the most representative way at a site. Dominant height at a reference age is used to classify stands in a fertility scale, and is closely linked to total production (Bentouati 2006). Many studies exist examining the productivity of stands across different countries in the Mediterranean (Pardé 1957, 1967, Decourt 1966, 1973, Souleres 1969, 1975, Garbaye et al. 1970, Yi 1976, Ottorini \& Nys 1981, M’hirit 1982, Toth \& Turrel 1983, Couhert \& Duplat 1993, Ammari et al. 2001, Sghaier et al. 2001, Sghaier \& Ammari 2012). Souleres (1969) showed that the production of Aleppo pine in Tunisia increased with the potential of the forest site, the bioclimatic stage, and soil fertility. For an average basal area of $7 \mathrm{~m}^{2}$, the annual productivity increases from $0.67 \mathrm{~m}^{3} \mathrm{ha}^{-1} \mathrm{yr}^{-1}$ in an arid bioclimate to $0.82 \mathrm{~m}^{3} \mathrm{ha}^{-1} \mathrm{yr}^{-1}$ in a semi-arid bioclimate, and finally to $0.95 \mathrm{~m}^{3} \mathrm{ha}^{-1} \mathrm{yr}^{-1}$ in a subhumid bioclimate. Sghaier \& Ammari (2012) showed that the average annual maximum growth of Aleppo pine is $3.3 \mathrm{~m}^{3}$ $\mathrm{ha}^{-1} \mathrm{yr}^{-1}$ at 40 years old in good forest sites, declining to less than $0.5 \mathrm{~m}^{3} \mathrm{ha}^{-1} \mathrm{yr}^{-1}$ for the fourth and last productivity class (i.e., at an age exceeding 100 years). Boudy (1950) and Chakroun (1986) stated that natural forests of Aleppo pine have very low production capacity, ranging from 0.5 to $3-4$ $\mathrm{m}^{3} \mathrm{ha}^{-1} \mathrm{yr}^{-1}$ at good forest sites. In comparison, artificial stands produce $1.2 \mathrm{~m}^{3} \mathrm{ha}^{-1} \mathrm{yr}^{-1}$ to $5.8 \mathrm{~m}^{3} \mathrm{ha}^{-1}$ year ${ }^{-1}$. For Aleppo pine at the reference age of 45 years, Ammari et al. (2001) estimated the total growing stock to be $154.96 \mathrm{~m}^{3} \mathrm{ha}^{-1}$ in fertility class $1,71.52$ $\mathrm{m}^{3} \mathrm{ha}^{-1}$ in fertility class $2,40.86 \mathrm{~m}^{3} \mathrm{ha}^{-1}$ in fertility class 3 , and $15.25 \mathrm{~m}^{3} \mathrm{ha}^{-1}$ in fertility class 4 . These classes were characterized by a reference dominant height of 4.5 and $13.5 \mathrm{~m}$. In addition, the average annual increment in volume ranged from 0.67 to 5.1 $\mathrm{m}^{3} \mathrm{ha}^{-1} \mathrm{yr}^{-1}$, depending on the fertility of the forest site. Bentouati (2006) reported that the Aleppo pine in Algeria was optimal at 50 years old, with growth in height significantly slowing down by 80 years old. This finding is consistent with the observations of Souleres (1969), who reported that the growth in height of Aleppo pine in Tunisia slowed down between 50 and 70 years old, depending on site conditions. Ciancio (1986) reported that the annual average increment in Italy ranged from $1.9 \mathrm{~m}^{3} \mathrm{ha}^{-1} \mathrm{yr}^{-1}$ at 25 years of age for the first fertility class to $12.2 \mathrm{~m}^{3} \mathrm{ha}^{-1} \mathrm{yr}^{-1}$ at 50 years old. Pardé (1956) documented a production of $4 \mathrm{~m}^{3}$ $\mathrm{ha}^{-1} \mathrm{yr}^{-1}$ on soil of exceptional fertility at a forest site in France for stands aged 75 years. In the Ouled Yagoub and Beni-Oudjana ranges in Algeria, the average volume increase of sampled stands in pine forests ranged from 0.5 to $4.8 \mathrm{~m}^{3} \mathrm{ha}^{-1} \mathrm{yr}^{-1}$ (Bentouati 2006).

The average maximum increase in volume for all classes combined peaks at $2.8 \mathrm{~m}^{3} \mathrm{ha}^{-1}$ $\mathrm{yr}^{-1}$ for the Ouled-Yagoub and Béni-Oudjana massifs in Algeria at the age of 80 . In comparison, the same value was reached at an earlier age ( $<60$ years) in stands in Spain. Furthermore, $2.6 \mathrm{~m}^{3} \mathrm{ha}^{-1} \mathrm{yr}^{-1}$ was documented at a reference age of 50 years for stands in Provence, France (Bentouati 2006). In Morocco, the productivity of stands in Tamga for three classes of fertility reached an average value of $2.53 \mathrm{~m}^{3} \mathrm{ha}^{-1}$ $\mathrm{yr}^{-1}$ for stands aged around 75 years (Belghazi et al. 2000). Serre-Bachet (1992) and Vila et al. (2008) investigated the structure and growth of Aleppo pine in Jebel Mansour, Tunisia, showing that rainfall enhanced growth, which was also closely associated to altitude and continentality. Guit et al. (2015) showed that altitude and exposure have a highly significant effect $(P<$ 0.001 ) on the dominant height and density of dendrometric parameters. Mérian \& Lebourgeois (2011) showed that there is a strong positive correlation between rainfall and radial tree growth. The growth of
Aleppo pine is optimal at sites between 100 and $300 \mathrm{~m}$ a.s.l. (Vennetier et al. 2010). In the French Mediterranean area and below $600 \mathrm{~m}$ a.s.l., the Aleppo pine exhibits major variation in growth related to its ecological requirements. It is generally well adapted to most types of forest sites, except for hydromorphic soils close to the surface. The main factors influencing the growth of Aleppo pine are related to the water balance of the forest site, while trophic balance only has a marginal effect (Vennetier et al. 2010). In Mediterranean forests, Aleppo pine has an average growth of 3 to $5 \mathrm{~m}^{3}$ $\mathrm{ha}^{-1} \mathrm{yr}^{-1}$ (Ricodeau 2013). Ciancio (1986) reported an average increase of 10 to $12 \mathrm{~m}^{3}$ $\mathrm{ha}^{-1} \mathrm{yr}^{-1}$ at a good forest site in Italy. Souleres (1969) concluded that, in Tunisia, artificial stands and stands resulting from fire regeneration had much higher productivity than natural forests, while productivity was lower in old stands. Tab. 1 presents the various studies on the growth of Aleppo pine that have been conducted in Tunisia and other countries, taking into account different classes of fertility and dominant tree height. Garchi (1991) showed that the fertility of Aleppo pine sites mainly depends on the depth of soil that can be exploited by the roots, humus thickness, soil texture, and the relief. Forest sites on little evolved soils with rich colluvial intake and a loam-clay texture have a fertility class 1 , and correspond to a site index of 13.5 to $16.5 \mathrm{~m}$ tree height for 50-year-old trees. Sites on calcareous brown soil and rendzine correspond to fertility class 2 , with a site index of 10.5 to $13.5 \mathrm{~m}$ for 50-year-old trees. Sghaier et al. (2001) identified four classes of fertility, with a reference height of 45 years in descending order: class 1 , with a reference height of $13.5 \mathrm{~m}$; class 2, with a reference height of $10.5 \mathrm{~m}$; class 3 , with a reference height of $7.5 \mathrm{~m}$; and class 4 , with a reference height of $4.5 \mathrm{~m}$. The authors concluded that about $49 \%$ of Aleppo pine stands in Tunisia belong to fertility class 3. Akrimi (1984) and Garchi (1991) studied the production of Aleppo pine in northwestern Tunisia (Sakiet region), showing that the most important production was between 0.4 and $4 \mathrm{~m}^{3} \mathrm{ha}^{-1} \mathrm{yr}^{-1}$ for a dominant height $(9.7-22.8 \mathrm{~m})$. The second most important production was defined by three classes of fertility, with the dominant height being between 5 and $15 \mathrm{~m}$. Couhert \& Duplat (1993) stated that, to obtain a high fertility class (Dominant height: $\mathrm{H}_{\text {dom }}=$ $16 \mathrm{~m}$ at 50 years old), the age of exploitation is 80 years, following three major thinnings at 30, 45, and 60 years. When considering total production and average annual increment, Aleppo pine stands belonging to the first productivity class in Tunisia are comparable to those belonging to the second productivity class in Spain and Algeria (Tab. 2). However, the average quadratic diameter of trees in Tunisia $(38 \mathrm{~cm})$, which seems to be directly related to density (Sghaier \& Ammari 2012), is intermediate between that of Algeria $(42.5 \mathrm{~cm})$ and 
Tab. 1 - Maximum average increases for Aleppo pine for different classes of fertility and dominant heights (Bentouati 2006). (MAG): Maximum average growth; $\left(\mathrm{H}_{\mathrm{dom}}\right)$ : dominant height; $\left(\mathrm{H}_{\mathrm{tot}}\right)$ : average total height.

\begin{tabular}{|c|c|c|c|c|c|}
\hline Authors & $\begin{array}{l}\text { Country } \\
\text { (Region) }\end{array}$ & Parameter & $\begin{array}{l}\text { Fertility } \\
\text { class }\end{array}$ & $\begin{array}{l}\text { Value } \\
(\mathrm{m})\end{array}$ & $\begin{array}{c}\text { MAG } \\
\left(\mathrm{m}^{3} \mathrm{ha}^{-1} \mathrm{yr}^{-1}\right)\end{array}$ \\
\hline \multirow[t]{3}{*}{ Couhert \& Duplat (1993) } & \multirow{3}{*}{$\begin{array}{l}\text { France } \\
\text { (Provence) }\end{array}$} & \multirow{3}{*}{$\mathrm{H}_{\mathrm{dom}}$ at $50 \mathrm{yrs}$} & 1 & 16 & 6 at 80 yrs \\
\hline & & & 2 & 12 & 3 at 70 yrs \\
\hline & & & 3 & 8 & 1 at 60 yrs \\
\hline \multirow[t]{3}{*}{ Pardé (1957) } & \multirow[t]{3}{*}{ France } & \multirow{3}{*}{$\mathrm{H}_{\text {tot }}$ at $75 \mathrm{yrs}$} & 1 & 21 & 4 \\
\hline & & & 2 & 18 & 3 \\
\hline & & & 3 & 14 & 1.5 \\
\hline \multirow[t]{6}{*}{ Brochiero et al. (1999) } & \multirow[t]{6}{*}{ France } & \multirow[t]{6}{*}{$\mathrm{H}_{\mathrm{dom}}$ at $70 \mathrm{yrs}$} & 1 & 23.4 & 5 at 70 yrs \\
\hline & & & 2 & 20.1 & 3 at $50 \mathrm{yrs}$ \\
\hline & & & 3 & 16.7 & 2 at $30 \mathrm{yrs}$ \\
\hline & & & 4 & 13.4 & 1 at $20 \mathrm{yrs}$ \\
\hline & & & 5 & 10 & - \\
\hline & & & 6 & 6.7 & - \\
\hline \multirow[t]{4}{*}{ Montero et al. (2001) } & \multirow[t]{4}{*}{ Spain } & \multirow{4}{*}{$\mathrm{H}_{\mathrm{dom}}$ at $60 \mathrm{yrs}$} & 1 & 20 & 4 at $50 \mathrm{yrs}$ \\
\hline & & & 2 & 17 & 3.1 at $50 \mathrm{yrs}$ \\
\hline & & & 3 & 14 & 2.4 at $60 \mathrm{yrs}$ \\
\hline & & & 4 & 11 & 1.5 at $70 \mathrm{yrs}$ \\
\hline \multirow[t]{3}{*}{ Belghazi et al. (2000) } & \multirow[t]{3}{*}{ Morocco } & \multirow[t]{3}{*}{$\mathrm{H}_{\mathrm{dom}}$ at $60 \mathrm{yrs}$} & 1 & 16.9 & 3.9 \\
\hline & & & 2 & 13.9 & 1.9 \\
\hline & & & 3 & 12.3 & 1.8 \\
\hline \multirow[t]{4}{*}{ Frantz \& Forster (1979) } & \multirow{4}{*}{$\begin{array}{l}\text { Algeria } \\
\text { (Béni-imloul) }\end{array}$} & \multirow[t]{4}{*}{$\mathrm{H}_{\mathrm{dom}}$ at $100 \mathrm{yrs}$} & 1 & 19 & 2.8 at 110 yrs \\
\hline & & & 2 & 16 & 2.21 at $50 \mathrm{yrs}$ \\
\hline & & & 3 & 13 & 1.6 at $120 \mathrm{yrs}$ \\
\hline & & & 4 & 10 & 1.10 at $130 \mathrm{yrs}$ \\
\hline \multirow[t]{4}{*}{ Ammari et al. (2001) } & \multirow[t]{4}{*}{ Tunisia } & \multirow[t]{4}{*}{$\mathrm{H}_{\mathrm{dom}}$ at $45 \mathrm{yrs}$} & 1 & 13.5 & 3.44 at $45 y r s$ \\
\hline & & & 2 & 10.5 & 1.59 at $45 \mathrm{yrs}$ \\
\hline & & & 3 & 7.5 & 0.91 at 45 yrs \\
\hline & & & 4 & 4.5 & 0.34 at $45 \mathrm{yrs}$ \\
\hline \multirow[t]{4}{*}{ Bentouati (2006) } & \multirow{4}{*}{$\begin{array}{l}\text { Algeria } \\
\text { (Oueld Yagoub, Béni Oudjana) }\end{array}$} & \multirow[t]{4}{*}{$\mathrm{H}_{\mathrm{dom}}$ at $70 \mathrm{yrs}$} & 1 & 19 & 4.40 at $70 \mathrm{yrs}$ \\
\hline & & & 2 & 16 & 3.3 at $80 \mathrm{yrs}$ \\
\hline & & & 3 & 13 & 2.3 at $80 \mathrm{yrs}$ \\
\hline & & & 4 & 10 & 1.4 at $90 \mathrm{yrs}$ \\
\hline
\end{tabular}

Spain (30.7 cm). Finally, El Khorchani (2006) showed that the radial growth of Aleppo pine declined significantly from 1950 to 2001, when investigating how climate change affects the productivity of this species. This decrease in the productivity of natural stands was attributed to increased water stress caused by decreased precipitation and increased temperatures.

\section{Production of cones and seeds}

Ayari (2012) showed that fructification is better in subhumid stands compared to semi-arid stands, possibly because the scarcity of rainfall and water resources in semi-arid stands. The subhumid environment seems to offer higher yields in terms of the number and weight of cones and seeds produced. These results are of great practical interest, enabling foresters to make better decisions for future reforestation programs. For instance, plantations in subhumid areas should be oriented preferentially towards seed production, whereas plantations in more arid areas (semi-arid and arid bioclimates) should serve other purposes, such as the conservation of water and soil. Previous research on the re- productive characteristics of conifers (Goubitz et al. 2002), seed dispersal (Benkman 1995, Lanner 1998), and sap levels (Moya et al. 2008) showed that several factors influence forest structure, including fire, erosion, and climate change (Fady et al. 2003). In a study conducted in a natural Aleppo pine forest at Jbel Mansour in Tunisia, Garchi \& Ben Mansoura (1999) showed that the forest stand consisted of a small proportion $(4.8 \%)$ of stems with an estimated diameter at breast height (DBH) greater than $30 \mathrm{~cm}$. Ayari et al. (2011a) showed that, in natural Aleppo pine forests in Tunisia, only $1.3 \%$ of trees had DBH $>30 \mathrm{~cm}$. Mencuccini et al. (1995) and Castagneri et al. (2008) showed that the structure of the forest in Italy mainly depended on the geographical variability of the forest site and/ or its density. Similarly, Ayari et al. (2011a) showed that optimum seed production was achieved when trees are $8 \mathrm{~m}$ tall (height) with $8 \mathrm{~m}$ crown diameter, with any increase in height or crown diameter having a positive effect on the production of cones and seeds.

Trees with large crowns might have better light reception, improving the rate of photosynthesis (Smith et al. 1988, Greene et al. 2002, Sutton \& Staniforth 2002). Ayari (2012), Ayari \& Khouja (2014), Esis et al. (1965), and Greene et al. (2002) confirmed that the production of cones and seeds is enhanced by a larger basal area. Thus, the morphological parameters of trees influence on their reproductive capacity (Ordonez et al. 2005, Turner et al. 2007). Ayari \& Khouja (2014) showed that a subhumid bioclimate enhances cone production over semi-arid climate. For instance, 117,036 cones ha- ${ }^{-1}$ and $119.2 \mathrm{~kg} \mathrm{ha}^{-1}$ of seeds were produced in a semi-humid stand, while 8,960-54,376 cones ha ${ }^{-1}$ and 88.1-110.7 kg $\mathrm{ha}^{-1}$ were produced in a semi-arid stand. One hectare of Aleppo pine forest in the Kef region, Tunisia, was estimated to produce $400 \mathrm{~kg}$ of cones every three years, corresponding to $10 \mathrm{~kg}$ seeds (cone to seed yield is $2.5 \%$ - MARHPT 2015). Ayari et al. (2011b) showed that the weight of seeds per cones was $1.72 \mathrm{~g}$ in a sub-humid area, while it was $1.12-1.53 \mathrm{~g}$ in a semi-arid area. In comparison, seed production was $261.5 \mathrm{~g}$ tree $^{-1}$ in a subhumid area, while it was 118.4$166.2 \mathrm{~g} \mathrm{tree}^{-1}$ in a semi-arid area. Cone weight per tree was $3.96 \mathrm{~kg}$ in a sub-humid 
Tab. 2 - Comparison of Aleppo pine production in Tunisia, Spain and Algeria (comparison at age 80 years) - Sghaier \& Ammari (2012). (Dg): mean quadratic diameter; $(\mathrm{N})$ : number of stems ha ${ }^{-1} ;(\mathrm{Hd})$ : dominant height; $(\mathrm{Vt})$ : total volume $\left(\mathrm{m}^{3} \mathrm{ha}^{-1}\right)$; (AAM): mean annual increment $\left(\mathrm{m}^{3} \mathrm{ha}^{-1} \mathrm{yr}^{-1}\right)$.

\begin{tabular}{|c|c|c|c|c|c|c|c|c|c|c|c|}
\hline \multirow{2}{*}{ Param } & \multicolumn{2}{|c|}{ Tunisia (class) } & \multicolumn{3}{|c|}{ Spain (class) } & \multicolumn{6}{|c|}{ Algeria (class) } \\
\hline & 1 & 2 & 3 & 1 & 2 & 3 & 4 & 1 & 2 & 3 & 4 \\
\hline $\mathrm{Dg}$ & 38.0 & 35.0 & 32.0 & 39.4 & 30.7 & 23.1 & 18.0 & 50.9 & 42.5 & 34.0 & 25.5 \\
\hline$N$ & 248.0 & 201.0 & 149.0 & 246.0 & 408.0 & 684.0 & 862.0 & 169.0 & 197.0 & 237.0 & 300.0 \\
\hline $\mathrm{Hd}$ & 15.9 & 12.8 & 9.6 & 20.0 & 17.0 & 14.0 & 11.0 & 20.7 & 17.5 & 14.2 & 10.9 \\
\hline $\mathrm{Vt}$ & 250.9 & 142.8 & 66.3 & 285.1 & 230.1 & 185.7 & 113.8 & 350.1 & 264.1 & 184.3 & 107.5 \\
\hline AAM & 3.1 & 1.8 & 0.8 & 3.6 & 2.9 & 2.3 & 1.41 & 4.4 & 3.3 & 2.3 & 1.3 \\
\hline
\end{tabular}

area, while it was $1.6-2.4 \mathrm{~kg}$ in a semi-arid area. Finally, there were 160 cones per tree in a sub-humid area, while there were 70119 cones per tree in a semi-arid area. Ayari et al. (2016) showed that there was an average of 8-97 cones tree ${ }^{-1}$, with an average cone weight of 15-20.6 g, the average cone weight per tree weight was 137.7-2018.6 g, and an average seed weight per tree of 7.382. 9 g. Ayari (2012) showed that tree density has a significant negative effect on the number and weight of cones and/or the number and weight of seeds/cone. For instance, production is almost halved when the density of Aleppo pines in forests rises from 250 to 1000 trees ha ${ }^{-1}$. To enhance the harvest of cones and seeds, Ayari (2012) suggested an optimal density of 250 trees $\mathrm{ha}^{-1}$. Ayari (2012) confirmed that the production yield of cones and seed was less important for stands with low densities and high basal areas. Furthermore, any increase in diameter at breast height enhanced profitability. Similarly, Smith et al. (1988), Arista \& Talavera (1996), and Karlsson \& Orlander (2002) concluded that the rate of fruiting in conifers is reduced in stands with high density. The decrease in cone and seed production was explained by a reduction in leaf photosynthesis activity (McDowell et al. 2000, Delzon et al. 2005).

Thus, reducing the density of Aleppo pine trees would enhance processes associated with regeneration and fruiting (Moya et al. 2009, Ayari et al. 2010). Ayari (2012) showed that the effect of tree age on cone and seed production is secondary to that of the dendrometric variables of the tree. Moreover, Ayari et al. (2011a, 2011b) showed that altitude has a significant effect on the number of seeds per cone and the number of seeds per hectare. Thus, any increase in ground elevation should lead to heavier cones, with a weight gain of up to $6.8 \mathrm{~g}$ between $250 \mathrm{~m}$ and $1185 \mathrm{~m}$ a.s.l. (Ayari 2012). Regarding the effect of site exposure on fructification in conifers, Ferrio et al. (2003) showed that slopes facing $\mathrm{NE}, \mathrm{SE}, \mathrm{S}$, and NW in a typical Mediterranean climate (characterized by optimal temperatures, sufficient light and moderate humidity) enhanced tree growth. Ayari (2012) obtained similar results, showing that slopes facing NE, NW, S, and SE enhanced seed production in the Aleppo pine forests of Tunisia. Thus, slopes with these exposures should be selected in future reforestation efforts of Aleppo pine, to maximize seed production. In Tunisia, the areas proposed for harvesting Aleppo pine cones and seeds by the forest services range from 60 to 100,000 ha in size. Overall, the national production of Aleppo pine seeds (or zgougou) is in the order of 300 to 320 tons per year. The Kasserine Governorate is the main region producing Aleppo pines, with an average production of 100 to 120 tons of seeds per year. The Siliana Governorate also has a center of production, conservation, and marketing, with an annual production of 40 to 50 tons of seeds.

The Kef Governorate produces just 10 tons per year, despite its importance in terms of Aleppo pine coverage. At present, national consumption is estimated at $1.5 \mathrm{~kg}$ seeds or $500 \mathrm{~g}$ of zgougou ground per family per year, with an upward trend. Over the next two years, an increase up to $2 \mathrm{~kg}$ of ground zgougou per family per year is expected (MARHPT 2015). The consumption of Aleppo pine seeds is a typical Tunisian tradition, and is constantly increasing across years. The seeds are marketed throughout the country on the festival of Mouled (a religious feast), and used to prepare the zgougou cream, also known as Assida in Tunisia. Such cream is marketed in some pastries and, even, some restaurants, while ground seeds are marketed throughout the year in grocery stores and supermarkets.

\section{Socio-economic role of the Aleppo pine in Tunisia}

In addition to its ecological role, Aleppo pine in Tunisia has a significant productive potential that should not be neglected, given the size of the areas occupied by this species. At the socio-economic and cultural level, few studies have been conducted on Aleppo pine, despite its multiple and diverse uses, including the production of seeds for human consumption. The decision to consume Aleppo pine seeds is justified by the specific taste of their aroma and by their high nutritional value (Way 2006). In 2012, the national consumption of seeds of the Aleppo pine was in the order of 300 to 320 tons, with a family consuming $1.5 \mathrm{~kg}$ of seeds or $500 \mathrm{~g}$ of ground zgougou per year, with a predicted upward

\section{trend (GIZ 2014).}

The Aleppo pine is a very important forest species that forms an important component of the national economy and human being in Tunisia. Aleppo pine seeds are the product most sought after by consumers and farmers. The seeds represent the main non-wood forest product at the socio-economic level by regional and local forestry services. In addition to their direct consumption as a pastry cream, several products available on the market are based on the Aleppo pine seeds, including yoghurt, aromatic ice creams and vegetable oil. Aleppo pine seeds are a true national wealth and source of income for many families. In total, 2334 farmers harvest of this product, employing 3000 seasonal workers and generating about 625,000 $€$ year $^{-1}$ of revenue (MARHPT 2015). The collection of cones for sale is a dangerous, though this activity generate an additional income for workers. At the micro-enterprise stage, zgougou businesses are profitable. The exploitation of the Aleppo pine meets strict criteria, including the obligation of specifications, the conclusion of operating contracts, and technical monitoring. Seed extraction in an area of one ha is estimated to return $32 €$. Based on a selling price of $5 €$ per $\mathrm{kg}$ of seeds, the total revenue per hectare is estimated at $50 €$. The profit margin generated by one ha in one year out of three is of the order of $16 € \mathrm{ha}^{-1}$ (MARHPT 2015). In Tunisia, the cream prepared from the flour extracted from Aleppo pine seeds, commonly called Assida zgougou, has an authentic flavor and confirmed nutritional value based on its calorific, lipid, and carbohydrate content. According to the National Institute of Consumption in Tunisia (INC), 100 grams of Assida, covered with a layer of cream and dried fruit, provides nearly 595 calories, or $25 \%$ of the daily energy needed by an adult. Without ornamental substances, the nutritional value of this same quantity is estimated at 275 calories.

\section{Suggestions to enhance seed production}

El Guemri (2018) showed that the reforestation density of Aleppo pine should be 1111 trees ha ${ }^{-1}$, because under these condition, four times more Aleppo pine seeds are harvested per hectare in the Northeast 
of Tunisia compared to the Northwest of Tunisia. Thus, the reforestation of Aleppo pine trees should be directed towards seed production in the Northeast of Tunisia and oriented towards wood production in the Northwest of Tunisia. Several factors had a combined effect on Aleppo pine seed/cone production in natural forests growing in Tunisia. Ayari et al. (2011a) suggested that bioclimatic areas with higher moisture conditions have a positive effect on fructification, producing greater cone crops and seed yields. The sub-humid zone produces greater quantities of cones and seeds (with higher mean yields) compared to other bioclimatic areas in Tunisia. Geographical variability of the bioclimatic areas is associated with the latitude, longitude, elevation, and land aspect (Ayari 2012).

Overall, longitudinal gradients represent the strongest geographical determinant causing a marked increase in cone dimensions and seed content, mainly in the semiarid zone. High consistency was found regarding the effect of elevation and longitude on cone dimensions and average individual seed mass (Ayari et al. 2011b). The effect of the geographical distribution on fructification is greater under drought conditions (Schiller \& Atzmon 2009). Furthermore, NE, NW, S, and SE facing slopes are the optimal aspects to enhance the cone harvests of Aleppo pine stands, and should be considered in future reforestation efforts (Ayari et al. 2011a). These suggestions on optimal site characteristics is expected to help Mediterranean foresters enhance cone and seed production by choosing appropriate locations for future Aleppo pine plantations. This research offers easy-touse suggestions for owners/managers to recognize the best reproductive sites for Aleppo pine forests and to increase the profitability of stands. This information might also help to satisfy the growing demand for Aleppo pine seed consumption, especially in Tunisia.

\section{Conclusions and future perspectives}

The sustainability of forest ecosystems depend on their management. Regeneration method represents a key phase in the life of a stand, as it determines its composition and structure in the long term. Indeed, achieving the most abundant regeneration possible is often a stated goal. It is necessary to maintain the sustainability of ecosystems and their ecosystem services within the context of silvicultural plans, allowing foresters to select individual trees that reflect the overall management objectives and ensure the production to serve human households. Low economic value and poor technological characteristics of Aleppo pine products have not favored more ambitious silviculture in the past. Several authors (Sghaier \& Ammari 2012, Garchi et al. 2001) placed more emphasis on the importance of Aleppo pines in protecting the environment over production in Tunisia. How- ever, today, seed production represents a very promising niche, especially for human consumption (pastry, ice creams, flour, etc.). Aleppo pine seeds also have many other medicinal and cosmetic uses, and high added value. Sylviculture oriented towards the commercial production of Aleppo pine seeds could only enhance the importance of this species in Northern Africa.

\section{References}

Acherar M, Lepart J, Debussche M (1984). La colonisation des friches par le pin d'Alep en Languedoc méditerranéen [Colonization of old fields by Aleppo pine in a Mediterranean part of France]. Acta oecologica 5 (2): 179-189. [in French] [online] URL: http://geoprodig.cnrs.fr/ items/show/159516

Akrimi N (1984). Relations entre production et sols dans la pineraie de Sakiet Sidi Youcef (Tunisie septentrionale) [Relations between production and soils in the pine plantation of Sakiet Sidi-Youssef (Northern Tunisia)]. Ph.D. thesis, University of Aix-Marseille, France, pp. 179. [in French] [online] URL: http://www. secheresse.info/spip.php?article23783

Alaoui A, Laaribya S, Gmira N (2011). Production, croissance et modèles de conduite sylvicoles des principales essences (le pin maritime et le pin d'Alep) de reboisement au Maroc [Production, growth and silvicultural management patterns of the main species (maritime pine and Aleppo pine) of reforestation in Morocco]. Faculty Journal of Forestry 11 (1): 68-84. [in French] [online] URL: https://www.researchga te.net/publication/317317813

Ammari Y, Sghaier T, Khaldi A, Garchi S (2001). Productivité du pin d'Alep en Tunisie: table de production [Productivity of Aleppo pine in Tunisia: table of production]. Annales de l'Institut National de Recherches en Génie Rural, Eaux et Forêts (INRGREF), Tunisia, vol. 4, pp. 43-51. [in French]

Arista M, Talavera S (1996). Density effect on the fruit-set, seed crop viability and seedling vigour of Abies pinsapo. Annals of Botany 77 (2): 187192. - doi: 10.1006/anbo.1996.0021

Aussenac G (1987). Effets de l'éclaircie sur l'écophysiologie des peuplements forestiers [Effects of thinning on the ecophysiology of forest stands]. Schweizerische Zeitschrift für Forstwesen 138 (8): 685-700. [in French]

Ayari A, Moya D, Ben Mansoura A, Rajeb MN, Garchi S, De Las Heras J, Henchi B (2010). Forest stand characteristic and individual tree size influences on Aleppo pine fructification and species conservation. In: Proceedings of the "International Symposium on the Biology of Rare and Endemic Plant Species (BIORARE)". Fethiye, Mugla (Turkey) 26-29 May 2010. Ministry of Environment and Forestry, FethiyeMugla, Turkey, pp. 39-40.

Ayari A, Moya D, Rejeb MN, Ben Mansoura A, Albouchi A, De Las Heras J, Fezzani T, Henchi B (2011a). Geographical variation on cone and seed production of Pinus halepensis Mill. natural forests in Tunisia. Journal of Arid Environments 75 (5): 403-410. - doi: 10.1016/j.jaridenv.20 11.01.001

Ayari A, Moya D, Rejeb MN, Ben Mansoura A, Garchi S, De Las Heras J, Henchi B (2011b). Al- ternative sampling methods to estimate structure and reproductive characteristics of Aleppo pine forests in Tunisia. Forest Systems 20 (3): 348-360. - doi: 10.5424/fs/20112003-10982 Ayari A (2012). Effets des facteurs environnementaux sur la fructification de pin d'Alep ( $\mathrm{Pi}$ nus halepensis Mill.) en Tunisie. [Effects of environmental factors on the fruiting of Aleppo pine (Pinus halepensis Mill.) in Tunisia]. Thèse de doctorat en Science Biologique, Faculté des Sciences de Tunis, Tunisie, pp. 230. [in French] [online] URL: https://www.researchgate.net/pu blication/260185216

Ayari A, Khouja ML (2014). Ecophysiological variables influencing Aleppo pine seed and cone production: a review. Tree Physiology 34: 426437. - doi: 10.1093/treephys/tpu022

Ayari A, Meftahi M, Zammeli F, Khouja ML (2016). Seed production variability of Aleppo Pine (Pinus halepensis Mill.) within Korbus Arboretum (North East of Tunisia). Global Journal of Botanical Science 4: 20-23. - doi: 10.12974/23 11-858X.2016.04.01.3

Bedel J (1986). Aménagement et gestion des peuplements de pin d'Alep dans la zone méditerranéenne française [Management and management of Aleppo pine stands in the French Mediterranean area]. Options Méditerranéennes, Série Etude CIHEAM 1: 109-125. [in French] [online] URL: http://om.ciheam.org/om/pdf/s10/ Cl010857.pdf

Belghazi B (1998). Eclaircies dans les plantations de pins [Thinning in pine plantations]. Thème 4, Rapport de mission, Deuxième projet de développement forestier PDF II, INRGREF, Tunisia, pp. 21. [in French]

Belghazi B, Ezzahiri M, Romane F (2000). Productivité de peuplements naturels de pin d'Alep (Pinus halepensis Mill.) dans la forêt de Tamga (Haut Atlas, Maroc). [Productivity of natural stands of Aleppo pine (Pinus halepensis Mill.) in the Tamga forest (High Atlas, Morocco)]. Forêt Méditerranéenne 21 (4): 521-529. [in French] [online] URL: http://www.foretmediterraneenne.org/upload/biblio/FORET_ME D_2000_4_521-529.pdf

Benkman CW (1995). Wind dispersal capacity of pine seeds and the evolution of different seed dispersal modes in pines. Oikos 73 (2): 221-224. doi: $10.2307 / 3545911$

Bentouati A (2006). Croissance, productivité et aménagement des forêts de pin d'Alep (Pinus halepensis Mill.) du massif de Ouled Yagoub (Khenchela-Aurès) [Growth, productivity and management of the Aleppo pine (Pinus halepensis Mill.) forests of the Ouled Yagoub massif (Khenchela-Aurès)]. Doctorat d'Etat en Sciences Agronomiques, Université El Hadj, Faculté des Sciences, Département d'Agronomie, Lakhdar-Batna, Algeria, pp. 108. [in French]

Boudy $P$ (1950). Economie forestière Nord-africaine - Tome 2: monographies et traitements des essences forestières [North African forest economics - Vol. 2: monographs and treatments of forest tree species]. Edition La Rose, Paris, France, pp. 878. [in French]

Boudy $P$ (1952). Guide du forestier en Afrique du nord [North Africa forestry guide]. Edition Maison Rustique, Paris, France, pp. 505. [in French] Breda N, Granier A, Aussenac G (1995). Effects of thinning on soil water balance and tree water 
relations, transpiration and growth in oak forest (Quercus petraea [Matt] Liebl.). Tree Physiology 15 (5): 295-306. - doi: 10.1093/treephys/15. 5.295

Brochiero F, Chandioux O, Ripert C, Vennetier M (1999). Autécologie et croissance du pin d'Alep en Provence calcaire [Autecology and height growth of Aleppo pine in Provence]. Forêt Méditerranéenne 20 (2): 83-94. [in French]

Castagneri D, Vacchiano G, Lingua E, Motta R (2008). Analysis of intraspecific competition in two subalpine Norway spruce (Picea abies (L.) Karst.) stands in Paneveggio (Trento, Italy). Forest Ecology and Management 255 (3-4): 651659. - doi: 10.1016/j.foreco.2007.09.041

Chakroun ML (1986). Le pin d'Alep en Tunisie. Etude, Le pin d'Alep et le pin brutia dans la sylviculture méditerranéenne [The Aleppo pine in Tunisia, Aleppo pine and Brutia pine in Mediterranean forestry]. Options Méditerranéennes, Série d'études 1: 25-27. [in French] [online] URL: http://om.ciheam.org/article.php?IDPDF= Clo10848

Cherak I (2010). Facteurs d'échec et de réussite des reboisements de pin d'Alep dans trois stations: Ain-Touta, Tazoult et Bouilef [Factors of failure and success of the reforestation of Aleppo pine in three sites: Ain-Touta, Tazoult and Bouilef]. Master's thesis in Agronomic Sciences, Université El Hadj Lakhdar, Faculté des Sciences, Département d'Agronomie, Batna, Algérie, pp. 107. [in French]

Ciancio O (1986). Le pin d'Alep et le pin brutia dans la sylviculture méditerranéenne: sylviculture de pin d'Alep [Aleppo pine and pine brutia in Mediterranean forestry: Aleppo pine silviculture]. Options Méditerranéennes: Série Etudes 1: 47-54. [in French] [online] URL: http://om. ciheam.org/om/pdf/s10/Cl010851.pdf

Clutter JL, Fortson JC, Pienaar LV, Brister GH, Bailey RL (1983). Timber management: a quantitative approach. John Wiley and Sons, New York, USA, pp. 333.

Couhert B, Duplat P (1993). Le pin d'Alep. Rencontres forestiers-chercheurs en forêt méditerranéenne [The Aleppo pine. Forest researchers meetings in the Mediterranean forest]. Éditions INRA, Paris, France, vol. 63, pp. 125-147. [in French]

Davis LS, Johnson KN (1987). Forest management ( $3^{\text {rd }}$ edn). McGraw-Hill, New York, USA, pp. 790.

Davis LS, Johnson KN, Bettinger PS, Howard TE (2001). Forest management to sustain ecological, economic and social values ( $4^{\text {th }}$ edn). McGraw Hill, New York, USA, pp. 804.

Decourt N (1966). Instructions pour l'assiette et les mensurations des placettes temporaires et semi-permanentes [Instructions for the attitude and measurements of temporary and semi-permanent forest compartment]. Annales des Sciences Forestieres 2: 286-289. [in French] Decourt N (1973). Protocole d'installation et de mesures des placettes de production semi-permanentes [Protocol for installation and measurement of semi-permanent production plots]. Document CNRF/INRA, Institut National de la Recherche Agronomique (INRA), France, pp. 25. [in French]

Delzon S, Bosc A, Cantet L, Loutau D (2005). Variation of the photosynthetic capacity across a chronosequence of maritime pine correlates with needle phosphorus concentration. Annals of Forest Sciences 62 (6): 537-543. - doi: 10.1051/ forest:2005046

DGF (2010). Inventaire national forestier de la Tunisie. Inventaire des forêts par télédétection. Résultats du deuxième inventaire forestier et pastoral national [National Forest Inventory of Tunisia. Inventory of forests by remote sensing. Results of the second national forest and pastoral inventory]. Direction Générale des Forêts, Ministère de l'Agriculture et des Ressources Hydrauliques, Tunis, Tunisie, pp. 88. [in French] Donner BL, Running SW (1986). Water stress response after thinning Pinus contorta in Montana. Forest Science 32 (3): 614-625. - doi: 10.10 93/forestscience/32.3.614

Ducrey M, Huc R (1999). Effets de l'éclaircie sur la croissance et le fonctionnement éco-physiologique d'un taillis de chêne vert [Effects of thinning on the growth and eco-physiological functioning of a holm oak coppice]. Revue Forestiere Francaise 2: 326-340. [in French] - doi: $10.4267 / 2042 / 5440$

D’hanens G (1998). Les peuplements mixtes de pin d'Alep et chênes en Provence [Mixed stands of Aleppo pine and oaks in Provence]. Forêt Méditerranéenne 19 (3): 261-266. [in French]

El Guemri R (2018). Production et valeur culturelle des graines du pin d'Alep de la forêt de Melloul (Cap Bon) [Production and cultural value of Aleppo pine seeds from the Melloul forest (Cap Bon)]. Mastère professionnel en sauvegarde et valorisation du patrimoine, ISMPT, Tunis, Tunisia, pp. 65. [in French]

El Hamrouni A, Sarson M (1975). Relation entre le couvert végétal et la régénération naturelle de Pinus halepensis Mill. [Relationship between vegetation cover and natural regeneration of Pinus halepensis Mill.]. Annales de l'Institut National de Recherches Forestières de Tunisie 7: 10-11. [in French]

El Khorchani A (2006). Approche dendrochronologique de l'influence des changements climatiques sur la productivité des forêts de pin d'Alep (Pinus halepensis Mill.) en Tunisie [A dendrochronological approach to the influence of climate change on the productivity of Aleppo pine (Pinus halepensis Mill.) forests in Tunisia]. Thèse de doctorat, Université Paul Cézanne, Aix-Marseille, France, pp. 211. [in French]

Esis S, Garman EH, Ebelli LF (1965). Relation between cone production and diameter increment of Douglas fir (Pseudotsuga menziesii (Mirb.) Franco), Grand fir (Abies grandis (Dougl.) Lindl.), and western white pine (Pinus monticola Dougl.). Canadian Journal of Botany 43 (12): 1553-1559. - doi: 10.1139/b65-165

Fady B, Semerci H, Vendramin GG (2003). Pinus halepensis and Pinus brutia - Technical guidelines for genetic conservation and use for Aleppo and Brutia pine. European Forest Genetic Resources Programme (EUFORGEN), International Plant Genetic Resources Institute, Rome, Italy, pp. 6.

Ferrio JP, Florit A, Vega A, Serrano L, Voltas J (2003). Delta $\mathrm{C}-13$ and tree-ring width reflect different drought responses in Quercus ilex and Pinus halepensis. Oecologia 137: 512-518. - doi: 10.1007/s00442-003-1372-7
Frantz F, Forster H (1979). Table de production de pin d'Alep pour les Aurès (Algérie) [Production table of Aleppo pine for Aurès (Algeria)]. Chair of Forest Production, University of Munich, Germany, pp. 114. [in French]

Garbaye J, Leroy PH, Le Tacon F, Levy G (1970). Réflexions sur une méthode d'études des relations entre facteurs écologiques et caractéristiques des peuplements. [Reflections on a method of studying the relationship between ecological factors and stand characteristics]. Annales des Sciences Forestières 27 (3): 303321. [in French] - doi: 10.1051/forest/19700305 Garchi S, Ben Mansoura A (1999). Influence de l'ombrage sur la structure et l'accroissement du pin d'Alep à Jbel Mansour [Influence of shading on the structure and growth of Aleppo pine at Jbel Mansour]. Annales de l'Institut National de Recherches en Génie Rural, Eaux et Forêts, Tunis, Tunisia, vol. 3, pp. 89-102. [in French]

Garchi S (1991). Approche multidimensionnelle de la typologie et de la cartographie des stations à pin d'Alep de la région de Touiref (Tunisie Septentrionale) [Multidimensional approach to the typology and mapping of Aleppo pine sites in the Touiref region (northern Tunisia)]. Thèse doctorat, Université Catholique, Faculté des Sciences Agronomique, Louvain, Belgium, pp. 219. [in French]

Garchi S, Ammari Y, Sghaier T, Khaldi A (2001). Etude du comportement du pin d'Alep en Tunisie [Study of the behavior of Aleppo pine in Tunisia]. Annales de l'Institut National de Recherches en Génie Rural, Eaux et Forêts, Tunis, Tunisia, pp. 147-162. [in French]

GIZ (2014). Analyse des chaînes de valeur des produits forestiers non ligneux en Tunisie: zgougou, lentisque et myrte [Value chain analysis of non-timber forest products in Tunisia: zgougou, lentisc and myrtle]. Projet "Adaptation au changement climatique des politiques forestières dans la région MENA", Ministère de l'environnement et de développement durable, Tunis, Tunisia, pp. 63. [in French]

Goubitz S, Werger MJA, Shmida A, Neeman G (2002). Cone abortion in Pinus halepensis Mill.: the role of pollen quantity, tree size and cone location. Oikos 97 (1): 125-133. - doi: 10.1034/j.16 00-0706.2002.970113.x

Greene DF, Messier C, Asselin H, Fortin MJ (2002). The effects of light avaibility and basal area on cone production in Abies balsamea and Picea glauca. Revue Canadienne de Botanique 80 (4): 370-377. - doi: 10.1139/bo2-020

Guit B, Nedjimi B, Guibal F, Chakali G (2015). Dendroécologie du pin d'Alep (Pinus halepensis Mill.) en fonction des paramètres stationnels dans le massif forestier de Senalba (Djelfa, Algérie) [Dendroecology of Aleppo pine (Pinus halepensis Mill.) based on the stationary parameters in the Senalba forest (Djelfa, Algeria)]. Revue d'Ecologie (Terre et Vie) 70 (1): 32-43. [in French]

Jalel T (1996). Historique des reboisements en Tunisie [Reforestation history in Tunisia]. Séminaire sur les reboisements en Tunisie, Direction générale des Forêts, Sousse, Tunisie, pp. 1-15. [in French]

Jiménez $E$, Vega JA, Pérez-Gorostiaga $P$, Cuiñas $\mathrm{P}$, Fonturbel T, Fernandez C, Madrigal J, Her- 
nando C, Gijarro M (2008). Effects of pre-commercial thinning on transpiration in young postfire maritime pine stands. Forestry 81 (4): 543 557. - doi: 10.1093/forestry/cpno32

Karlsson C, Orlander G (2002). Mineral nutrients in needles of Pinus sylvestris seed trees after release cutting and their correlation with cone production and seed weight. Forest Ecology and Management 166 (1-3): 183-191. - doi: 10.10 16/S0378-1127(01)00684-3

Langley R (1976). Etude de la régénération naturelle du pin d'Alep en Tunisie centrale (Oum Djeddour) [Study of the natural regeneration of Aleppo pine in central Tunisia (Oum Jeddour)]. Project TUN/540, Renforcement et Développement de l'INRF, Institut National de Recherches Forestières, Ariana, Tunisia, pp. 15. [in French]

Lanner RM (1998). Seed dispersal in Pinus. In: "Ecology and Biogeography of Pinus" (Richardson DM eds). Cambridge University Press, New York, USA, pp. 527281-295.

Letreuch Belarouchi N (1991). Les reboisements en Algérie et leur perspective d'avenir [Reforestation in Algeria and their future perspective]. Office des Publications Universitaires, Algiers, Algeria, pp. 641.

MARHPT (2015). Formulation du programme de gestion des ressources naturelles dans les territoires ruraux vulnérables de Tunisie. Document de travail: fiche filière graines de pin d'Alep EI Ksour, Ain Fdhil, El Ksour (Le Kef) [Formulation of the Natural Resource Management Program in the Vulnerable Rural Territories of Tunisia. Working document: Alep El Ksour Pine Seed File, Ain Fdhil, El Ksour (Le Kef)]. Département de la production végétale, Ministère de l'Agriculture, des Ressources Hydrauliques et de la Pêche de Tunisie, Tunis, Tunisia, pp. 30. [in French]

McDowell SC, McDowell NG, Marshall JD, Hultine $K$ (2000). Carbon and nitrogen allocation to male and female reproduction in rocky mountain Douglas-fir (Pseudotsuga menziesii var. glauca, Pinaceae). American Journal of Botany 87 (4): 539-546. - doi: 10.2307/2656598

Mencuccini M, Piussi P, Zanzi Sulli A (1995). Thirty years of seed production in a subalpine Norway spruce forest: patterns of temporal of spatial variation. Forest ecology and Management76 (1-3): 109-125. - doi: 10.1016/0378-1127 (95)03555-O

Misson L, Nicault A, Guiot J (2003). Effects of different thinning intensities on drought response in Norway spruce (Picea abies (L.) Karst.). Forest Ecology and Management 183 (1-3): 47-60. doi: 10.1016/S0378-1127(03)00098-7

Montero G, Canellas I, Ruis-Peinado R (2001). Growth and yield models for Pinus halepensis Mill. Investigación Agraria. Sistemas y Recursos Forestales 10 (1): 179-201.

Moya D, De Las Heras J, Lopez-Serrano FR, Leone $V$ (2008). Optimal intensity and age management in young Aleppo pine stands for post-fire resilience. Forest Ecology and Management 255 (8-9): 3270-3280. - doi: 10.1016/j.foreco.2008.01. 067

Moya D, De Las Heras J, Lopez-Serrano FR, Conedès S, Alberdi I (2009). Structural patterns and biodiversity in burned and managed Aleppo pine stands. Plant Ecology 200 (2): 217-228. doi: 10.1007/s11258-008-9446-6

Mérian P, Lebourgeois F (2011). Size-mediated climate growth relationships in temperate forests: a multi-species analysis. Forest Ecology and Management 261: 1382-1391. - doi: 10.1016/j. foreco.2011.01.019

M'hirit O (1982). Etude écologique et forestière des cédraies du Rif marocain. Essai sur une approche multidimensionnelle de la phytoécologie et $\mathrm{d}$ e la productivité du cèdre (Cedrus atlantica Manetti) [Ecological and forestry study of cedar forests of the Moroccan Rif. Multivariate approach to phytoecology and cedar productivity (Cedrus atlantica Manetti)]. Thèse de Doctorat, Université de Droit Economique et Sciences, Aix-Marseille, France, pp. 436. [in French]

Neveux M, Duhen LM, Corti JM, Devallois P, Fontanel JL, Boiseau P (1986). Plaidoyer pour une sylviculture du pin d'Alep par les techniciens du terrain [Advocacy for silviculture of Aleppo pine by field technicians]. Forêt Méditerranéenne 8 (1): 13-18. [in French]

Nsibi R (1997). Relation entre le couvert végétal et la régénération naturelle des forêts de pin d'Alep dans la région de Sakiet Sidi Youssef [Relationship between vegetation cover and natural regeneration of Aleppo pine forests in Sakiet Sidi Youssef region]. Diplôme des Etudes Approfondies, Université de Tunis II, Faculté des Sciences de Tunis, Tunisie, pp. 74. [in French]

Ordonez JL, Retana J, Espelta JM (2005). Effects of tree size, crown damage, and tree location on post-fire survival and cone production of $\mathrm{Pi}$ nus nigra trees. Forest Ecology and Management 206 (1): 109-117. - doi: 10.1016/j.foreco.20 04.10 .067

Ottorini JM, Nys C (1981). Application des données de l'inventaire forestier national à l'étude de la production du Pin sylvestre en Margeride: etude de la croissance en hauteur [Application of national forest inventory data to the study of Scots pine production in Margeride: study of height growth]. Annals of Forest Science 38 (2): 223-236. [in French] - doi: 10.1051/forest:19 810204

Pardé J (1956). Une notion pleine d'intérêt: la hauteur dominante des peuplements forestiers [A concept full of interest: the dominant height of forest stands]. Revue Forestière Française (12): 850-856. [in French] - doi: 10.4267/20 $42 / 27262$

Pardé J (1957). La productivité des forêts de pin d'Alep en France [Productivity of Aleppo pine forests in France]. Annales de la Section de la Station de Recherches et Expériences Forestières 15 (2): 367-414. [in French]

Pardé J (1967). Réflexion sur la productivité des forêts françaises [Reflection on the productivity of French forests]. Centre National de Recherches Forestières, Nancy, France, pp. 485. [in French]

Quezel P, Médail F (2003). Ecologie et biogéographie des forêts du bassin méditerranéen [Ecology and biogeography of forests in the Mediterranean basin]. Éditions scientifiques et médicales, Elsevier /Lavoisier, Paris, France, pp. 571. [in French]

Ricodeau N (2013). Développement de modèles sylvicoles de Pin d'Alep. Quelle est la valeur du
Pin d'Alep? [Development of silvicultural models of Aleppo pine. What is the value of Aleppo Pine?]. Mémoire de fin d'études, L'Institut des Sciences et Industries du Vivant et de l'Environnement, AgroParisTech, Paris, France, pp. 60. [in French]

Schiller G, Atzmon N (2009). Performance of Aleppo pine (Pinus halepensis) provenances grown at the edge of the Negev desert: a review. Journal of Arid Environments 73: 10511057. - doi: 10.1016/j.jaridenv.2009.06.003

Serre-Bachet F (1992). Les enseignements écologiques de la variation de l'épaisseur du cerne chez le pin d'Alep [Ecological teachings of variation in ring thickness in Aleppo pine]. Forêt Méditerranénne 8 (3): 171-176. [in French]

Sghaier T, Ammari Y, Garchi S, Khaldi A (2001). Croissance en hauteur et classes de fertilité du pin d'Alep [Growth in height and fertility classes of Aleppo pine]. Annales de I'Institut National de Recherche en Génie Rural, Eaux et Forêts, Tunisie, Numéro Spécial 4, pp. 45-53. [in French]

Sghaier T, Garchi S (2009). Modélisation de la croissance en hauteur dominante et fertilité des peuplements de pin d'Alep (Pinus halepensis Mill.) en Tunisie [Modeling dominant height growth and fertility of Aleppo pine (Pinus halepensis Mill.) Stands in Tunisia]. Ecologia Mediterranea 35: 49-63. [in French]

Sghaier T, Ammari Y (2012). Croissance et production du pin d'Alep (Pinus halepensis Mill.) en Tunisie [Growth and production of Aleppo pine (Pinus halepensis Mill.) in Tunisia]. Ecologia Mediterranea 38 (1): 39-57. [in French] [online] URL: http://www.researchgate.net/publication/ 259284590

Smith CC, Hamrick JL, Hramer CL (1988). The effects of stand density on frequency of filled seeds and in lodgepole pine (Pinus contorta Dougl.). Canadian Journal of Forest Research 18 (4): 453-460. - doi: 10.1139/x88-066

Souleres G (1969). Le pin d'Alep en Tunisie [Aleppo pine in Tunisia]. Annales de I'Institut National de Recherches Forestiers INRF, Tunisie, vol. 2, pp. 126. [in French]

Souleres G (1975). Classes de fertilité et production des forêts tunisiennes de pin d'Alep [Fertility classes and production of Tunisian pine forests]. Revue forestière française 27 (1): 4149. [in French] - doi: 10.4267/2042/20915

Sutton A, Staniforth RJ (2002). Reproductive ecology and allometry of red pine (Pinus resinosa) at the northwestern limit of its distribution range in Manitoba, Canada. Canadian Journal of Botany 80 (5): 482-493. - doi: 10.1139/bo2031

Toth J, Turrel M (1983). La productivité du pin noir d'Autriche dans le sud-est de la France [Productivity of Austrian black pine in southeastern France]. Revue Forestière Française 35 (2): 111-120. - doi: 10.4267/2042/21636

Tschinkel H (1976). Effets de l'élimination de la végétation concurrente sur l'humidité du sol et sur la réussite des reboisements avec Pinus halepensis Mill. [Effects of removal of competing vegetation on soil moisture and successful reforestation with Pinus halepensis Mill.]. Note de Recherches, National Forest Research Institute of Tunisia (INREF), Tunisia, vol. 11, pp. 15. [in French] 
Turner MG, Turner MD, Romme WH, Tinker DB (2007). Cone production in young post-fire $\mathrm{Pi}$ nus contorta stands in greater Yellowstone (USA). Forest Ecology and Management 242 (23): 119-126. - doi: 10.1016/j.foreco.2006.12.032 Vennetier $M$ (2003). La régénération du pin d'Alep après incendie. [Regeneration of Aleppo pine after fire]. Info DFCl, Bulletin du Centre de Documentation "Forêt Méditerranéenne et Incendie", no. 50, CEMAGREF, Aix-en-Provence, France, pp. 8. [in French] [online] URL: http:// cemadoc.irstea.fr/cemoa/PUB00018398

Vennetier $M$, Ripert C, Brochiéro $F$, Rathgeber CBK, Chandioux O, Estève R (2010). Evaluation de la croissance du pin d'Alep en région méditerranéenne française [Assessment of the growth of Aleppo pine in the French Mediterranean region]. Revue Forestière Française 5: 11. [in French]. [online] URL: http://hal.archivesouvertes.fr/hal-00593706

Vila B, Vennetier M, Ripert C, Chandioux O, Liang EY, Guibal F, Torre F (2008). Les changements globaux ont-ils déjà induit des changements de croissance en forêt méditerranéenne? Le cas du pin d'Alep et du pin sylvestre de la saintebaume (Bouches-du-Rhône). [Have global changes already induced growth changes in the Mediterranean forest? The case of the Aleppo pine and Scots pine of the holy balsam (Bouches-du-Rhône)]. Forêt Méditerranéenne
29 (2): 161-166. [in French]

Way S (2006). Strategic management of Aleppo pines on Lower Eyre Peninsula to maximise biodiversity conservation outcomes. Department for Environment and Heritage, Port Lincoln, Australia, pp. 54.

Yi BG (1976). Croissance du cèdre de l'Atlas (Cedrus atlantica Manetti), en relation avec quelques variables du milieu en Languedoc-RoussilIon (France) [Growth of Atlas cedar (Cedrus atlantica Manetti), in relation to several environmental variables in Languedoc-Roussillon (France)]. Thèse de Doctorat, Université des Sciences et Techniques du Languedoc, Montpellier, France, pp. 133. [in French] 